Eskişehir Osmangazi Üniversitesi

Sosyal Bilimler Dergisi

Nisan 2019, 20 (Özel Sayı), 393-411

DOI: 10.17494/ogusbd.548521

\title{
Üstün Zekâlı Birinci Sınıf Öğrencilerinin İlk Okuma ve Yazma Hatalarının Incelenmesi*
}

\author{
Esra ERTÜRK, Coşkun KÜçÜKTEPE* ${ }^{* *}$
}

Üstün Zekâlı Birinci Sınıf Öğrencilerinin İlk Okuma ve Yazma Hatalarının Incelenmesi

\section{Özet}

Araştırmanın amacı, üstün zekâlı birinci sınıf öğrencilerinin ilk okuma-yazma hatalarını belirlemektir. Araştırma deseni olarak nitel araştırma desenlerinden durum çalışması, veri toplama aracı olarak doküman incelemesi kullanıımıştır. Çalışma grubu, amaçı̈ı örnekleme yöntemlerinden ölçüt örnekleme yoluyla seçilen 2017-2018 yıllarında İstanbul'da öğrenim gören üstün zekâlı 30 birinci sınıf öğrencisinden oluşmaktadır. Veriler nitel içerik analiziyle çözümlenmiş, "Sesli Okuma Hataları Ölçeği" ve "Yazma Hataları Ölçeği" ile değerlendirme yapılmıştır. Değerlendirmeler sonucunda üstün zekâlı öğrencilerin en fazla "okurken atlama" ve " vurguya dikkat etmeden okuma" hatalarını yaptığı görülmüştür. Öğrencilerin "ilk okuma-yazmaya başlama ve ilerleme" ile "bağımsız okuma ve yazma" aşamasındaki hataları incelenmiş, bu aşamalar arasında tüm yazma hatalarında azalma, "cümleye küçük harfle başlama", "kelimeler arasında fazla boşluk bırakma", "satıra yanlış yerden başlayarak yazma" hatalarında artış olduğu saptanmıştır.

Anahtar Kelimeler: Üstün Zekâ Eğitimi, İlk Okuma ve Yazma, Üstün Zekâlı Öğrenci, Okuma Hataları, Yazma Hataları
Investigation of First Reading and Writing Failures of Gifted First Grade Students

Abstract

The aim of this research is to determine the first reading and writing mistakes of gifted first grade students. The research design was used as a case study from qualitative research designs and the document review was used as data collection tool. The study group consisted of 30 gifted students who continued their education in a private school in Istanbul during the 2017-2018 academic year, which was selected through benchmark sampling from purposeful sampling methods. The data was analyzed by qualitative content analysis, "Voice Reading Error Scale" and "Writing Error Scale". As a result of the evaluations, it was seen that gifted students made most of these mistakes; "escape while reading" and "reading without paying attention to emphasis". Students' mistakes in steps "first reading and writing" and "independent reading and writing " were examinated in detail and while a decrease was seen in all writing mistakes between these two steps, an increase was determined in these three mistakes; "starting sentence with lowercase", "leaving too much space between words" and "writing the line from the wrong place".

Key Words: Gifted Intelligence, First Reading and Writing, Gifted Student, Reading Errors, Writing Errors

\section{Giriş}

Eğitim; geçmişin, günümüzün ve geleceğin en büyük ihtiyaçlarından biridir. Bireylerin ve dolayısıyla toplumların gelişmesi, ilerlemesi, yeniliklere uyum sağlaması, üretmesi ve bulunduğu çağa uyum sağlamasının yegâne temeli eğitimdir.

\footnotetext{
*Bu çalışma 2018 yılında Bahçeşehir Üniversitesi, Eğitim Bilimleri Enstitüsü, Üstün Zekâlılar ve Yetenekliler Eğitimi Anabilim Dalı'na sunulmuş yayınlanmamış yüksek lisans tezinden türetilmiştir.

** Esra ERTÜRK, Uzm., srrtrk@gmail.com, ORCID ID orcid.org / 0000-0001-5093-6024; Coşkun KÜçÜKTEPE, Doç. Dr., İstanbul Üniversitesi Cerrahpaşa, Eğitim Bilimleri Bölümü, ckucuktepe@gmail.com ORCID ID orcid.org / 0000-00033908-964X
} 
Formal eğitimin temelleri okuma ve yazma süreci ile ilkokul birinci sınıf itibari ile atılır. Eğitimin temellerinin atıldığı ilk okuma yazma eğitimi öğrencinin kazandığı en temel akademik kazanımdır. ilk okuma ve yazma kazanımı diğer derslerde ve sosyal hayatta önemli bir kilit noktasıdır (Şahin, 2009). Öğrencinin akademik hayatının temellerinin atıldığı bu adımda sadece akademik başarının değil aynı zamanda öğrencinin sosyal hayatının da bir gerekliliğidir. Illk okuma ve yazma, tüm dersler için anahtar rolü oynayan, temel okuma ve yazma becerilerinin yanı sıra düşünme, anlama, sıralama, sorgulama, sınıflama, ilişki kurma, değerlendirme, analiz ve sentez yapma gibi zihinsel süreçleri de kapsayan eğitim sisteminin temelini oluşturan beceridir (Pilten, Temur, Şahin ve Demir, 2009).

Bu sebeple okuma yazma eğitiminin, öğrencinin hayatında kazandığı en önemli becerilerin başında geldiği söylenebilir. Bu öğretim sırasında yaşanabilecek bazı hatalar mevcuttur. Bu hatalar okuma ve yazma hataları olarak iki başlıkta incelenir. Bu aşamada öğrencilerin hatalarının kalıcı hale gelmemesi için, yaptıkları hatalarla ilgili mutlaka hızlı bir şekilde geribildirim verilmelidir.

Öğrencilerin okuma ve yazma sürecinde yaptıkları hataların birçok sebebi olabilir. Bu sebeple öğrencinin öğrenme stili, hızı ve becerilerine yönelik eğitim içeriği sunulmaması sayılabilir. Bu durumlar öğrencilerin gelişim düzeyleri ile ilgili olduğu için, öğrencilerin gelişim özellikleri ilk okuma ve yazma öğretiminde son derece önemlidir.

Gelişim özellikleri farklıık gösteren öğrenciler özel eğitime ihtiyaç duyarlar. Özel eğitim; standart eğitim ve öğretim programları ile eğitilemeyen öğrenciler için düzenlenen eğitimdir denebilir. Özel eğitime ihtiyacı olan öğrenci gruplarından bir tanesi de üstün zekâlı öğrencilerdir. Zekâ somut olmayan ama var olduğu bilinen zihinsel bir güçtür ve zekâ düzeyi yüksek olan bireylerin zihinleri fazlasıyla gizemlidir (Sak, 2014). Üstün zekâda sadece IQ'ya dayalı olmayan bir tanım Renzulli'nin Üç Halka Modeli'dir. Bu tanıma göre üstün zekâ ve yetenek, ortalamanın üzerinde bir IQ sokuru, yaratıcılık ve görevi tamamlama motivasyonu gibi üç özelliğin bir arada olmasına bağlıdır (Eriş, 2015). Aynı zamanda birçok uzman; üstün zekâyı bilgiyi işleme ve problem çözme becerisinin diğerlerinden hızlı olması şeklinde yorumlar (Kahveci, 2016). Üstün zekâlı öğrenciler ise hızlı öğrenir (Hollingworth, 1942), ilgi alanları geniştir (Bloom, 1982), hafızaları güçlüdür (Freeman, 1985), yaratıcıdırlar (Louise \& Lewis, 1992), hayal güçleri geniştir (Schiever, 1985), algılama yetenekleri gelişmiştir (Price \& Milgram, 1993). Dil gelişimleri açısından üstün zekâlı ve yetenekli öğrencilere bakıldığında, erken konuşan üstün zekâlı öğrencilerin altı yaşına geldikleri zaman kusursuz okuyucular olmaları yüksek bir ihtimaldir (Dale, Crain-Thoreson \& Robinson, 1995). Üstün zekâlı öğrencilerin kelime dağarcıkları geniştir (Cutts \& Moseley, 2004), dil gelişimleri hızlıdır (Clark, 2002), okumayı yaşıtlarından önce öğrenirler (Martinson, 1961), bu sebeple de kitap okumaktan büyük zevk alırlar (Cox, 1977).

Üstün zekâlı bireylerin olağanüstü potansiyellerini ortaya çıkarmak ve geliştirmek için ihtiyaçları olan eğitim içeriğini sağlamak gerekir. Üstün zekâlı öğrencilerin en fark edilebilir karakteristik özelliği olağanüstü dil gelişimleridir (Witty, 1963). Literatür incelendiğinde üstün zekâlı öğrencilerin 
diğer öğrencilerden çok daha önce okuma ve yazmayı öğrendikleri veya okula başladıktan birkaç hafta sonra süreci tamamladıkları görülmektedir. Ancak üstün zekâlı öğrenciler bu okuma yazma sürecini informal bir ortamda tamamlar. Formal bir eğitim almadan kendi kendine okuma ve yazma öğrenen öğrencilerin, formal eğitim alan öğrencilere göre yaptıkları okuma ve yazma hatalarının da farklı olması beklenmektedir. Ayrıca okuma ve/veya yazma bilerek okula başlayan öğrenciler aynı zamanda okuma ve/veya yazma hataları ile de okula başlamaktadır. Üstün zekâlı öğrencilerin bu hatalarını önceden tespit etmenin okuma yazma sürecinin daha sağlıklı ilerlemesine olanak sağlayacağı düşünülmüş, araştırmada üstün zekâlı öğrencilerin yaptıkları sesli okuma ve yazma hatalarının incelenmesi amaçlanmış. Bu araştırmada üstün zekâlı ve yetenekli öğrencilerin yaptığı ilk okuma ve yazma hatalarının neler olduğu problemine cevap aranmıştır.

\section{1. Çalışmanın Amacı}

Bu çalışmanın temel amacı, üstün zekâlı birinci sınıf öğrencilerinin sesli okuma ve yazma hatalarını belirlemektir. Bu doğrultuda Ses Esaslı Öğretim Yöntemi ve dik temel harfler ile ilkokulda eğitim gören, "üstün zekâlı" tanısı almış birinci sınıf öğrencilerinin "bağımsız okuma ve yazma" aşamasında yaptıkları okuma hatalarını ve "okuma yazmaya başlama ve ilerleme" ile "bağımsız okuma ve yazma" aşamalarında yaptıkları yazma hatalarını belirlemek amaçlanmıştır.

Bu çalışma kapsamında "Üstün zekâlı birinci sınıf öğrencilerinin ilk okuma ve yazma sürecinde yapmış oldukları okuma ve yazma hataları nelerdir?" sorusu temel araştırma sorusu olarak belirlenmiştir. Bu temel soruya yanıt vermek amacıyla aşağıda belirlenmiş olan araştırma soruları üzerinde çalışılmıştır:

1. Üstün zekâlı birinci sınıf öğrencilerinin okumada ortaya çıkan hataları nelerdir?

2. Üstün zekâlı birinci sınıf öğrencilerinin "Okuma Yazmaya Başlama ve İlerleme" aşamasında ortaya çıkan yazım hataları nelerdir?

3. Üstün zekâlı birinci sınıf öğrencilerinin 'Bağımsız Okuma ve Yazma” aşamasında yaptıkları yazım hataları nelerdir?

4. Üstün zekâlı birinci sınıf öğrencilerinin "ilkk Okuma Yazmaya Başlama ve Illerleme" ile "Bağımsız Okuma ve Yazma" aşamasında yaptıkları yazım hataları karşılaştıııldığında dağılım nasıldır?

\subsection{Araştırmanın Önemi}

Ülkemizde daha önce normal zekâ düzeyindeki öğrenciler ile ilk okuma-yazma hatalarıyla ilgili çalışmalar yapılmıştır. Ancak bu çalışma, üstün zekâlı öğrencilerin ilk okuma ve yazma hatalarıyla ilgili ülkemizde yapılan ilk çalışma olması sebebiyle önemli olduğu düşünülmektedir. 
Esra ERTÜRK | Coşkun KÜÇÜKTEPE

\section{Yöntem}

\subsection{Araştırma Modeli}

Araştırmada nitel araştırma desenlerinden durum çalışması kullanılmışırı. Her durum çalışması sıkıcı olmadan ve detaylarda boğulmadan araştırmanın odağını aydınlatıcı derece detaylı ve kapsamlı olmalıdır. Durum çalışması, katıımcı gözlemleri, görüşmeler ve doküman incelemeleri ile elde edilen verilerin derinlemesine ve boylamsal olarak incelenmesini içerir. (Ersoy ve Yalçınoğlu, 2012). Bu sebeple, üstün zekâlı öğrencilerin okuma ve yazma hatalarının derinlemesine incelendiği bu araştırma da durum çalışmasına örnektir.

\section{2. Çalışma Grubu}

Araştırmanın çalışma grubunu, amaçlı örnekleme yöntemlerinden ölçüt örnekleme yoluyla seçilen 2017-2018 eğitim öğretim yılında, özel bir okulun İstanbul'daki 3 kampüsünde öğrenim gören ve üstün zekâlı tanısı almış 30 birinci sınıf öğrencisi oluşturmaktadır. Araştırmanın ölçütleri "birinci sınıf öğrencileri" ve "üstün zekâlı olarak tanılanmış öğrenciler" olarak araştırmacı tarafından belirlenmiştir ve çalışma grubu bu ölçütler doğrultusunda oluşturulmuştur. Bu sebeple, ölçüt örnekleme yöntemi kullanılmıştır.

\subsection{Verilerin Toplanması}

\subsubsection{Veri toplama araçları}

Araştırmada üstün zekâlı birinci sınıf öğrencilerinin ilk okuma ve yazma sürecindeki yazma hatalarını belirlemek amacıyla öğrencilerin yazı defterleri toplanmış, sesli okuma hatalarını belirlemek amacıyla araştırmacı tarafından seçilen metinler öğrencilere okutularak görüntülü kayıtları alınmıştır. Bu hataları saptamak amacıyla veri toplama aracı olarak doküman incelemesi kullanılmıştır.

\subsubsection{Veri toplama işlemleri}

Verilerin toplama işlemi, öğrencilerin "okuma yazmaya başlama ve ilerleme" aşamasının "metin oluşturma" evresi ve "bağımsız okuma ve yazma" evresinde olmak üzere iki farklı dönemde ve üç farklı uygulama ile gerçekleşmiştir. İlk uygulama "okuma yazmaya başlama ve ilerleme" aşamasında yazdırılan "Ben bir Çizgiyim" metniyle yapılmıştır. İkinci uygulama "bağımsız okuma ve yazma" aşamasında " Resim" metni yazdırılarak gerçekleşmiştir. Üçüncü uygulama da "Haberleşme Araçları" metni öğrencilere sesli okuma yaptırılarak "bağımsız okuma ve yazma" aşamasında yapılmıştır. Veriler öğrencilerin "metin oluşturma" evresindeki 2018 Şubat ayının son haftası ve "bağımsız okuma ve yazma" aşamasında bulundukları 2018 Nisan ayının ilk haftasında toplanmıştır. 


\subsubsection{Veri analiz işlemleri}

Analiz, kavramsal kodlama ve sınıflama yoluyla temaların ve bu temalar arasındaki anlamlı ilişkilerin ortaya çıkarılmasıdır. Coffey \& Atkinson (1996), verilerin analiz sürecinin kapsamlı ve sistematik bir şekilde olması gerektiği ancak bu sürecin her araştırmada standart olmadığını belirtmişlerdir.

Bu araştırmada doküman incelemesi yazılı ve görsel materyaller ile yapılmış ve nitel içerik analizi ile veri analiz işlemleri gerçekleştirilmiştir. İçerik analizi, tümevarım-tümdengelim yollarıyla, hem nicel hem de nitel verilerde kullanılabilen bir yöntemdir (Elo \& Kyngäs, 2007). İçerik analizinde, birbirine yakın olan veriler belirli kavramlar ve temalar çerçevesinde bir araya getirilir ve yorumlanır. Verilerin analizi aşamasında öncelikle elde edilen veriler kodlanır, bu kodlar belirli kategorilere ayrılarak temalar altında toplanır, veriler belirlenen kod ve temalara göre düzenlenir ve son olarak bulgular yorumlanır (Yıldırım ve Şimşek, 2016).

Araştırma kapsamında öğrencilerden toplanan veriler sonunda yapılan literatür araştırmasıyla okuma ve yazma hataları kapsamlı bir şekilde incelenmiş ve ortaya koyulan bu hatalarda dikkate alınarak araştırmacı tarafından tümevarımsal bir yaklaşımla öğrencilerin sesli okuma ve yazma hataları belirlenmiştir. Bu hataların belirlenme sürecinde öğrencilerin yaptığı her hata ile önce kodlar oluşturulmuş ve ardından kodların ortak özelliklerinden yola çıkılarak kodları içinde barındıran temalara ulaşılımışır. Tüm bu işlemler sonucunda "Sesli Okuma Hataları Formu" ve "Yazma Hataları Formu" oluşturulmuştur. Her bir öğrenci çalışması incelenirken ilk kez karşılaşılan hata için bütün kâğıtlar tekrar incelenmiştir.

Analiz aşamasında oluşturulan "Sesli Okuma Hataları Formu" ve "Yazma Hataları Formu" ile öğrencilerden toplanan veriler analiz edilmiştir. "Sesli Okuma Hataları Formu" 7 tema altında belirlenen 30 kod ile oluşturulmuştur. "Yazma Hataları Formu" 8 tema altında belirlenen 35 kod ile oluşturulmuştur. Her öğrencinin defteri ve videosu izlenirken saptanan yeni hatalar için analiz edilen diğer defter ve videolar tekrar incelenmiştir. Okuma ve yazma hataları için hata yapan öğrenci sayıları ile hatanın kaç kez yapıldığı hesaplanarak yüzde değerleri bulunmuştur.

Kodlamada geçerliliği sağlamak amacıyla uzman görüşünden yararlanılmıştır. Güvenirliği sağlamada ise ikinci bir araştırmacı tarafından tüm verilerin incelenip kodların oluşturulması sağlanmıştır. Araştırmacı tarafından okuma hatalarında 214, yazma hatalarında ise toplamda 628 kod saptanmıştır. İkinci bir araştırmacı tarafından okuma hatalarında 208, yazma hatalarında ise toplamda 596 kod saptanmıştır. Görüş birliği ve ayrılıkları karşılaştırması dikkate alınmış, Miles ve Huberman (1994) tarafından üretilen formül kullanılmış ve güvenirlik hesaplanmıştır.

\section{Görüş Birliği}

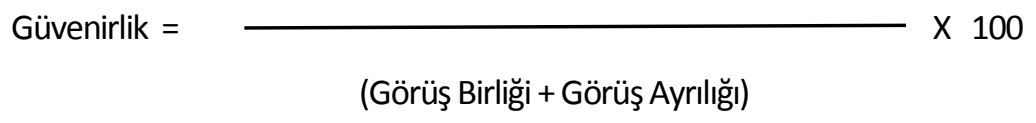


Bu formül kullanılarak okuma hatalarının kodlama güvenirliği 97.19, yazma hatalarının kodlama güvenirliği 94.90 olarak hesaplanmıştır.

\section{Bulgular ve Yorum}

\section{1. Üstün Zekâlı Öğrencilerin Sesli Okuma Hatalarına İlişkin Bulgular}

Araştırmanın birinci alt problemi olan "Üstün zekâlı birinci sınıf öğrencilerinin yaptığı okuma hataları nelerdir?" sorusuna yanıt aramak amacıyla 30 üstün zekâlı birinci sınıf öğrencisinin sesli okuma hataları "Haberleşme Araçları" metninin okutulması sonucunda belirlenmiştir.

Tablo 1. Öğrencilerin Sesli Okuma Hatalarına Illişkin Frekans ve Yüzde Dağılımı

\begin{tabular}{|c|c|c|}
\hline SESLIOKUMA HATALARI & $f$ & $\%$ \\
\hline \multicolumn{3}{|l|}{ Atlayarak Okuma } \\
\hline Hece atlama & 16 & 53,33 \\
\hline Başlığı atlama & 12 & 40 \\
\hline Ses atlama & 8 & 26,66 \\
\hline Satır Atlama & 6 & 20 \\
\hline Kelime atlama & 1 & 3,33 \\
\hline \multicolumn{3}{|l|}{ Ekleyerek Okuma } \\
\hline Ses ekleme & 9 & 30 \\
\hline Hece ekleme & 7 & 23,33 \\
\hline Kelime ekleme & 2 & 6,66 \\
\hline \multicolumn{3}{|l|}{ Tekrarlayarak Okuma } \\
\hline Heceyi tekrar okuma & 14 & 46,66 \\
\hline Kelimeyi tekrar okuma & 13 & 43,33 \\
\hline Sesi tekrar okuma & 6 & 40 \\
\hline Satırı tekrar okuma & 1 & 3,33 \\
\hline \multicolumn{3}{|l|}{ İzleyerek Okuma } \\
\hline Parmakla izleme & 7 & 23,33 \\
\hline \multicolumn{3}{|l|}{ Birleştirememeye Bağlı Hatalar } \\
\hline Heceleri birleştirmeden bağımsız okuma & 15 & 50 \\
\hline
\end{tabular}


Okuma Kurallarına Uymamaya Bağlı Hatalar

Vurguya dikkat etmeden okuma 16

53,33

Noktalama kurallarına dikkat etmeden okuma

13

43,33

Kelimeyi yanlış okuma

8

26,66

Sürekli sallanarak/başka materyalle ilgilenerek okuma

7

23,33

Önce içinden sessiz okuma yaparak okuma

3

Alt satıra geçerken fazla bekleme

3

Sürekli alçak ses tonuyla okuma

1

Anlaşılmayacak şekilde mırıldanarak okuma

1

Sürekli yutkunarak okuma

\section{Seslendirmeye Bağlı Hatalar}

Heceleyerek okuma

Sesleri farklı okuma

Göz ve yazı arasında yakın mesafede okuma

Sesleri yanlış telaffuz etme (Sesi ince ya da kalın okuma)

Sesleri uzatarak okuma

Seslerin yerini değiştirerek okuma

Tablo 1'de öğrencilerin sesli okuma hatalarına ait tema ve kodlar yer almaktadır. Tablo incelendiğinde çalışma gurubundaki 30 öğrencinin 16'sı tarafından yapılan "okurken hece atlama" ve "vurguya dikkat etmeden okuma" hatalarının en yüksek frekansa sahip olduğu görülmektedir. En yüksek frekansa sahip olan bu hataları 15 öğrenci tarafından yapılan "heceyi tekrarlayarak okuma" ve "heceleri birleştirmeden bağımsız okuma" hataları izlemektedir. Tablo incelendiğinde çalışma gurubundaki öğrencilerin en az yaptıkları okuma hatalarının 1 frekansa sahip "kelime atlama", "satırı tekrar okuma", "sürekli alçak ses tonuyla okuma", "anlaşılmayacak şekilde mırıldanarak okuma", "sürekli yutkunarak okuma" ve "hecelerin yerini değiştirerek okuma" okuma hataları olduğu belirlenmiştir. 


\section{2. Üstün Zekâlı Öğrencilerin "ilk Okuma Yazmaya Başlama ve ilerleme” Aşamasındaki Yazma Hatalarına ilişkin Bulgular}

Araştırmanın ikinci alt problemi olan 'Üstün zekâlı birinci sınıf öğrencilerinin "Okuma Yazmaya Başlama ve ilerleme" aşamasında yaptıkları yazım hataları nelerdir?" sorusuna yanıt aramak ama-

cıyla 30 üstün zekâlı birinci sınıf öğrencisinin "ilk okuma ve yazmaya başlama ve ilerleme" aşamasındaki hataları "Ben Bir Çizgiyim" metninden yola çıkarak belirlenmiştir.

Tablo 2. Öğrencilerin "ilk Okuma Yazmaya Başlama Ve Ilerleme” Aşamasında Yaptı̆̆ı Yazım Hatalarına İlişkin Frekans Ve Yüzde Dağılımı

YAZMA HATALARI

Uygun Aralığa Yazmamaya Bağlı Hatalar

Harflerin uzantısını kısa yapma

Harfleri ilgili aralıktan daha küçük yazma

Harfleri ilgili aralıktan daha büyük yazma

Harfi uygun olmayan aralığa yazma

Noktalama işaretlerini uygun olmayan aralığa yazma

Eksik Yazmaya Bağı Hatalar

Kelimedeki harflerin bir ya da birkaçını eksik yazma

Cümleyi eksik bırakma

Cümlede eksik kelime bırakma
$17 \quad 56,66$

$15 \quad 50$

$25 \quad 83,33$

1343,33

620

$27 \quad 90$

$7 \quad 23,33$

$7 \quad 23,33$

Ekleyerek Yazmaya Bağlı Hatalar

Kelimeye bir ya da birkaç harf ekleyerek yazma

$15 \quad 50$

Cümleye bir ya da birkaç kelime ekleyerek yazma

30

Yanlış Yazmaya Bağıı Hatalar

Harfleri şekline uygun yazmama

73,33

Kelimedeki harfin yerine başka bir harf yazma

$20 \quad 66,66$

Noktalama işaretlerini şekline uygun yazmama

$10 \quad 33,33$

Kelimedeki harflerin yerini değiştirerek yazma

620

Yazım Kurallarına Uymamaya Bağlı Hatalar 
Harfle yazılması gereken sayıları rakamla yazma

3

Kullanılmaması gereken yerde küçük harf kullanma

14

46,66

Kullanılmaması gereken yerde büyük harf kullanma

Birleşik kelimeleri bölerek yazma

Başlığı küçük harfle yazma

5

16,66

Satır sonuna sığmayan kelimeleri doğru ayırmadan yazma

8

26,66

Noktalama işaretlerini uygun yerde kullanmama

Ayrı yazılması gereken kelimeleri birleştirerek yazma

\section{Bırakılan Boşluklara Bağlı Hatalar}

Harfler arasında az boşluk bırakma

Harfler arasında fazla boşluk bırakma

Kelimeler arasında az boşluk bırakma

Kelimeler arasında fazla boşluk bırakma

Kelime ile soru eki arasında boşluk bırakmama

Cümleler arasında az boşluk bırakma

Cümleler arasında fazla boşluk bırakma

Yazı Yönüne Bağlı Hatalar

Noktalama işaretlerini ters yazma

Harfleri ters yazma

\section{Sayfa Düzenine Bağlı Hatalar}

Satıra yanlış yerden başlayarak yazma

Başlığı satııı ortalamadan yazma

Tablo 2'de yazma hatalarına ait tema ve kodlar yer almaktadır. Tablo incelendiğinde çalışma gurubundaki 30 öğrencinin \%90'ı tarafından yapılan "kelimedeki harflerin bir ya da birkaçını eksik yazma" hatasının en yüksek frekansa sahip olduğu belirlenmiştir. Bu hatayı öğrencilerin \%83,33'ünün yaptığı "harfleri ilgili aralıktan daha büyük yazma" hatası izlemektedir. Öğrencilerin en az yaptıkları yazma hatasının 1 öğrenciye ait olan "satıra yanlış yerden başlayarak yazma", yazma hatası olduğu belirlenmiştir. 


\section{Örnek 1}

Örnek 1"de öğrencinin "kelimedeki harflerin bir ya da birkaçını eksik yazma" ve "harfleri ilgili aralıktan daha büyük yazma" hatalarını yaptığı görülmüştür. Öğrenci "Oluyorum" ve "oyuncu" kelimelerini yazarken "o" harflerini ilgili aralıktan büyük, "pasta" kelimesini yazarken "a" harfini eksik yazmışır.

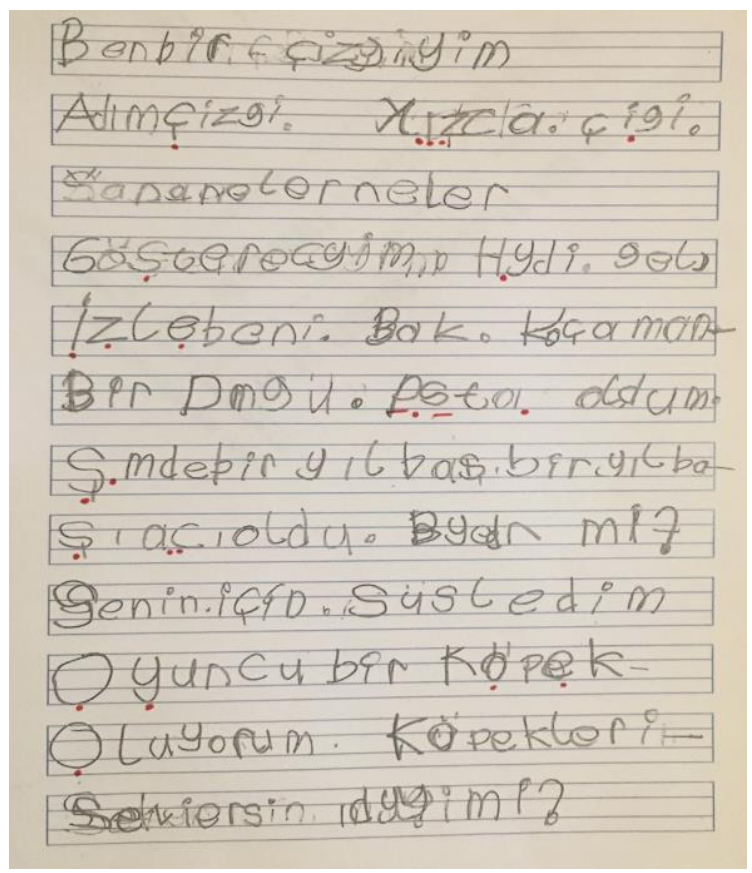

\section{3. Üstün Zekâlı Öğrencilerin "Bağımsız Okuma ve Yazma" Aşamasındaki Yazma Hatalarına} ilişkin Bulgular

Araştırmanın üçüncü alt problemi olan "Üstün zekâlı birinci sınıf öğrencilerinin 'Bağımsız Okuma ve Yazma" aşamasında yaptıkları yazım hataları nelerdir?" sorusuna yanıt aramak amacıyla 30 üstün zekâlı birinci sınıf öğrencisinin "bağımsız okuma ve yazma" aşamasındaki hataları "Resim" metninden yola çıkarak belirlenmiştir. 
Tablo 3. Öğrencilerin “Bağımsız Okuma ve Yazma” Aşamasında Yaptığı Yazım Hatalarına Iliş̧kin Frekans Ve Yüzde Dağıımı

\begin{tabular}{|c|c|c|}
\hline YAZMA HATALARI & $f$ & $\%$ \\
\hline \multicolumn{3}{|l|}{ Uygun Aralığa Yazmamaya Bağlı Hatalar } \\
\hline Harflerin uzantısını kısa yapma & 14 & 46,66 \\
\hline Harfleri ilgili aralıktan daha küçük yazma & 12 & 40 \\
\hline Harfleri ilgili aralıktan daha büyük yazma & 17 & 56,66 \\
\hline Harfi uygun olmayan aralığa yazma & 2 & 6,66 \\
\hline Noktalama işaretlerini uygun olmayan aralığa yazma & 4 & 13,33 \\
\hline \multicolumn{3}{|l|}{ Eksik Yazmaya Bağlı Hatalar } \\
\hline Kelimedeki harflerin bir ya da birkaçını eksik yazma & 19 & 63,33 \\
\hline Cümleyi eksik bırakma & 0 & 0 \\
\hline Cümlede eksik kelime bırakma & 1 & 3,33 \\
\hline \multicolumn{3}{|l|}{ Ekleyerek Yazmaya Bağlı Hatalar } \\
\hline Kelimeye bir ya da birkaç harf ekleyerek yazma & 10 & 33,33 \\
\hline Cümleye bir ya da birkaç kelime ekleyerek yazma & 2 & 6,66 \\
\hline \multicolumn{3}{|l|}{ Yanlış Yazmaya Bağlı Hatalar } \\
\hline Harfleri şekline uygun yazmama & 20 & 66,66 \\
\hline Kelimedeki harfin yerine başka bir harf yazma & 18 & 60 \\
\hline Noktalama işaretlerini şekline uygun yazmama & 1 & 3,33 \\
\hline Kelimedeki harflerin yerini değiştirerek yazma & 1 & 3,33 \\
\hline \multicolumn{3}{|l|}{ Yazım Kurallarına Uymamaya Bağlı Hatalar } \\
\hline Cümleye küçük harfle başlama & 14 & 46,66 \\
\hline Harfle yazılması gereken sayıları rakamla yazma & 2 & 6,66 \\
\hline Kullanılmaması gereken yerde küçük harf kullanma & 13 & 43,33 \\
\hline Kullanılmaması gereken yerde büyük harf kullanma & 9 & 30 \\
\hline Birleşik kelimeleri bölerek yazma & 6 & 20 \\
\hline Başlı̆̆ı küçük harfle yazma & 2 & 6,66 \\
\hline Satır sonuna sığmayan kelimeleri doğru ayırmadan yazma & 3 & 10 \\
\hline
\end{tabular}


Esra ERTÜRK | Coşkun KÜÇÜKTEPE

Noktalama işaretlerini uygun yerde kullanmama

10

33,33

Ayrı yazılması gereken kelimeleri birleştirerek yazma

0

0

\section{Bırakılan Boşluklara Bağlı Hatalar}

Harfler arasında az boşluk bırakma

26,66

Harfler arasında fazla boşluk bırakma 620

Kelimeler arasında az boşluk bırakma 310

Kelimeler arasında fazla boşluk bırakma $5 \quad 16,66$

Kelime ile soru eki arasında boşluk bırakmama

$0 \quad 0$

Cümleler arasında az boşluk bırakma $0 \quad 0$

Cümleler arasında fazla boşluk bırakma

Yazı Yönüne Bağlı Hatalar

Noktalama işaretlerini ters yazma $0 \quad 0$

Harfleri ters yazma

$5 \quad 16,66$

\section{Sayfa Düzenine Bağlı Hatalar}

Satıra yanlış yerden başlayarak yazma $5 \quad 16,66$

Başlığı satırı ortalamadan yazma $17 \quad 56,66$

Satır sonunda uygun boşluk bırakmama 15 50

Tablo 3 incelendiğinde öğrencilerin "bağımsız okuma ve yazma" aşamasında en yüksek oranla $(\% 66,66)$ "harfleri şekline uygun yazmama" hatasını yaptığı görülmektedir. En çok yapılan ikinci hata ise \%63,33 oranla "kelimedeki harflerin bir ya da birkaçını eksik yazma" hatasıdır. Öğrencilerin "bağımsız okuma ve yazma" aşamasında, "cümleyi eksik bırakma", "ayrı yazılması gereken kelimeleri birleştirerek yazma", "kelime ile soru eki arasında boşluk bırakmama", "cümleler arasında az boşluk bırakma" ve "noktalama işaretlerini ters yazma" hatalarını hiç yapmadıkları görülmektedir. 


\section{Örnek 2}

Örnek 2'de öğrencilerin "harfleri şekline uygun yazmama" ve "kelimedeki harflerin bir ya da birkaçını eksik yazma" hatalarını yaptığı görülmüştür. Öğrenci "Kollarını" kelimesini yazarken "l" harfi eksik yazmış ve "Kürsünün" kelimesini yazarken "ü" seslerini şekline uygun yazmamıştır. Öğrencinin diğer pek çok yerde aynı hataları yaptığı tespit edilmiştir.

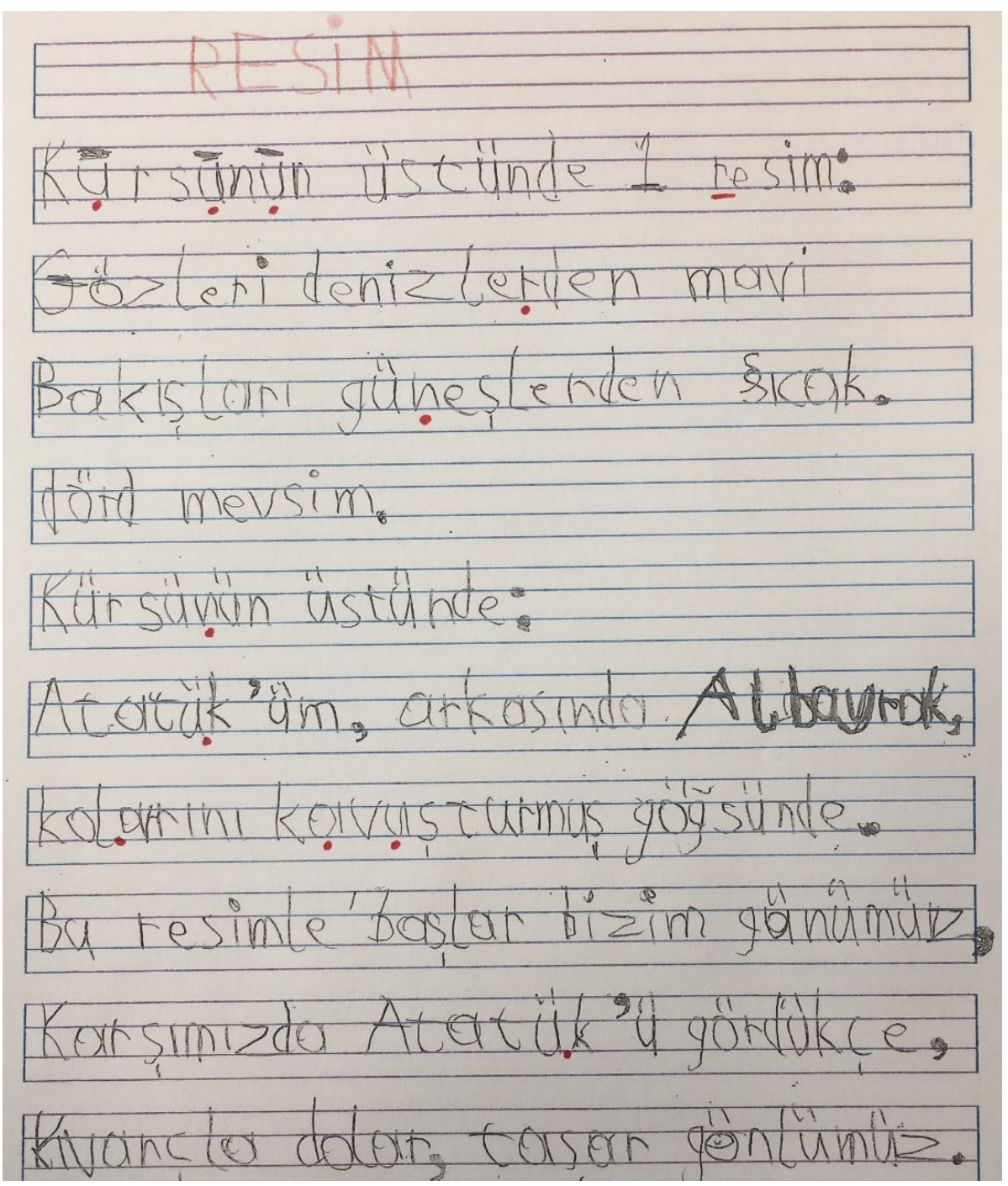




\section{4. Öğrencilerin "illk Okumaya Yazmaya Başlama ve İlerleme" ile "Bağımsız Okuma ve Yazma” Aşamalarındaki Yazma Hatalarının Karşılaştırılmasına iliş̧in Bulgular}

Araştırmanın dördüncü alt problemi olan "Üstün zekâlı birinci sınıf öğrencilerinin "illk Okuma Yazmaya Başlama ve Ilerleme" ile "Bağımsız Okuma ve Yazma" aşamasında yaptıkları yazım hataları karşılaştırıldığında dağılım nasıldır?" sorusuna yanıt aramak amacıyla öğrencilerin "ilk okuma yazmaya başlama ve ilerleme" ile "bağımsız okuma ve yazma" aşamasındaki hataları karşılaştırılarak dağılımları belirlenmiştir.

Tablo 4. Öğrencilerin "illk Okuma Yazmaya Başlama ve İlerleme (iOYBi)" ile "Bağımsız Okuma ve Yazma (BOY)" Aşamalarında Yaptıkları Yazım Hatalarının Karşılaştırılmasına illişkin Frekans Ve Yüzde Dağılımı

\begin{tabular}{|c|c|c|c|c|}
\hline \multirow[t]{2}{*}{ YAZMA HATALARI } & \multicolumn{2}{|l|}{ IOYBI } & \multicolumn{2}{|c|}{ BOY } \\
\hline & $f$ & $\%$ & $f$ & $\%$ \\
\hline \multicolumn{5}{|l|}{ Uygun Aralığa Yazmamaya Bağı Hatalar } \\
\hline Harflerin uzantısını kısa yapma & 17 & 56,66 & 14 & 46,66 \\
\hline Harfleri ilgili aralıktan daha küçük yazma & 15 & 50 & 12 & 40 \\
\hline Harfleri ilgili aralıktan daha büyük yazma & 25 & 83,33 & 17 & 56,66 \\
\hline Harfi uygun olmayan aralı̆̆a yazma & 13 & 43,33 & 2 & 6,66 \\
\hline Noktalama işaretlerini uygun olmayan aralığa yazma & 6 & 20 & 4 & 13,33 \\
\hline \multicolumn{5}{|l|}{ Eksik Yazmaya Bağlı Hatalar } \\
\hline Kelimedeki harflerin bir ya da birkaçını eksik yazma & 27 & 90 & 19 & 63,33 \\
\hline Cümleyi eksik bırakma & 7 & 23,33 & 0 & 0 \\
\hline Cümlede eksik kelime bırakma & 7 & 23,33 & 1 & 3,33 \\
\hline \multicolumn{5}{|l|}{ Ekleyerek Yazmaya Bağıı Hatalar } \\
\hline Kelimeye bir ya da birkaç harf ekleyerek yazma & 15 & 50 & 10 & 33,33 \\
\hline Cümleye bir ya da birkaç kelime ekleyerek yazma & 9 & 30 & 2 & 6,66 \\
\hline \multicolumn{5}{|l|}{ Yanlış Yazmaya Bağlı Hatalar } \\
\hline Harfleri şekline uygun yazmama & 22 & 73,33 & 20 & 66,66 \\
\hline Kelimedeki harfin yerine başka bir harf yazma & 20 & 66,66 & 18 & 60 \\
\hline Noktalama işaretlerini şekline uygun yazmama & 10 & 33,33 & 1 & 3,33 \\
\hline
\end{tabular}




\begin{tabular}{|c|c|c|c|c|}
\hline Kelimedeki harflerin yerini değiştirerek yazma & 6 & 20 & 1 & 3,33 \\
\hline \multicolumn{5}{|l|}{ Yazım Kurallarına Uymamaya Bağlı Hatalar } \\
\hline Cümleye küçük harfle başlama & 12 & 40 & 14 & 46,66 \\
\hline Harfle yazılması gereken sayıları rakamla yazma & 3 & 10 & 2 & 6,66 \\
\hline Kullanılmaması gereken yerde küçük harf kullanma & 14 & 46,66 & 13 & 43,33 \\
\hline Kullanılmaması gereken yerde büyük harf kullanma & 21 & 70 & 9 & 30 \\
\hline Birleşik kelimeleri bölerek yazma & 14 & 46,66 & 6 & 20 \\
\hline Başlığı küçük harfle yazma & 5 & 16,66 & 2 & 6,66 \\
\hline Satıra sığmayan kelimeleri doğru ayırmadan yazma & 8 & 26,66 & 3 & 10 \\
\hline Noktalama işaretlerini uygun yerde kullanmama & 19 & 63,33 & 10 & 33,33 \\
\hline Ayrı yazııması gereken kelimeleri birleştirerek yazma & 3 & 10 & 0 & 0 \\
\hline \multicolumn{5}{|l|}{ Bırakılan Boşluklara Bağlı Hatalar } \\
\hline Harfler arasında az boşluk bırakma & 7 & 23,33 & 2 & 6,66 \\
\hline Harfler arasında fazla boşluk bırakma & 13 & 43,33 & 6 & 20 \\
\hline Kelimeler arasında az boşluk bırakma & 12 & 40 & 3 & 10 \\
\hline Kelimeler arasında fazla boşluk bırakma & 4 & 13,33 & 5 & 16,66 \\
\hline Kelime ile soru eki arasında boşluk bırakmama & 6 & 20 & 0 & 0 \\
\hline Cümleler arasında az boşluk bırakma & 6 & 20 & 0 & 0 \\
\hline Cümleler arasında fazla boşluk bırakma & 3 & 10 & 1 & 3,33 \\
\hline \multicolumn{5}{|l|}{ Yazı Yönüne Bağlı Hatalar } \\
\hline Noktalama işaretlerini ters yazma & 4 & 13,33 & 0 & 0 \\
\hline Harfleri ters yazma & 9 & 30 & 5 & 16,66 \\
\hline \multicolumn{5}{|l|}{ Sayfa Düzenine Bağlı Hatalar } \\
\hline Satıra yanlış yerden başlayarak yazma & 1 & 3,33 & 5 & 16,66 \\
\hline Başlığı satırı ortalamadan yazma & 23 & 76,66 & 7 & 56,66 \\
\hline Satır sonunda uygun boşluk bırakmama & 23 & 76,66 & 15 & 50 \\
\hline
\end{tabular}


Esra ERTÜRK | Coşkun KÜÇÜKTEPE

hatasıdır. Tablo incelendiğinde "illk okuma yazmaya başlama ve ilerleme" aşamasında \%3,33 oranıyla en az yapılan hata "satıra yanlış yerden başlayarak yazma" hatasıdır. Ayrıca öğrenciler "bağımsız okuma ve yazma" aşamasında, "cümleyi eksik bırakma", "ayrı yazılması gereken kelimeleri birleştirerek yazma", "kelimeler arasında fazla boşluk bırakma", "kelime ile soru eki arasında boşluk bırakmama" ve "noktalama işaretlerini ters yazma" hatalarını hiç yapmamıştır. Çalışma grubundaki üstün zekâlı öğrencilerin "ilk okuma yazmaya başlama ve ilerleme" aşamasından "bağımsız okuma ve yazma" aşamasına geçtikten sonra "cümleye küçük harfle başlama" hatasında \%6,66, "kelimeler arasında fazla boşluk bırakma" hatasında \%3,33 ve "satıra yanlış yerden başlayarak yazma" hatasında \%13,33 oranlarında artış belirlenmiştir. Sonuç olarak yazma hataları ile ilgili belirlenmiş olan 35 hatadan yukarıda belirtilen 3 hata dışındaki 32 hatada "bağımsız okuma ve yazma" aşamasında azalma saptanmıştır.

\section{Sonuç ve Tartışma}

\subsection{Tartışma}

Üstün zekâlı birinci sınıf öğrencilerinin ilk okuma yazma eğitiminde "ilk okuma yazmaya başlama ve ilerleme" aşamasındaki sesli okuma ve yazma hataları ile "bağımsız okuma ve yazma" aşamasındaki yazma hatalarını belirlemek amacıyla yapılan bu araştırmada öğrencilerin okuma hatalarını belirlemek amacıyla yapılan video kayıtları analiz edildiğinde, okuma bilerek okula başlayan öğrencilere ait en fazla hatanın "hece atlama" olduğu, okuma bilmeden okula başlayanların ise, "heceleri birleştirmeden bağımsı okuma" ve "vurguya dikkat etmeden okuma" hataları olduğu görülmüştür. Sesli okuma hatalarında kız öğrencilerin hatalarının erkek öğrencilerden fazla olduğu ve tüm öğrencilere ait en fazla hataların "okurken hece atlama" ve "vurguya dikkat etmeden okuma" hataları olduğu görülmüştür.

Akyol ve Temur (2008) tarafından yapılan bir araştırmada birinci sınıf öğrencilerinin en fazla "heceleme" hatası yapıldığını bulmuştur. Bununla birlikte en sık yapılan hataların "eksik okuma", "tekrarlı okuma", "düzeltme" ve "ekleme" olduğu tespit edilmiştir. Söz konusu araştırma normal zekâ düzeyindeki öğrencilerde yapıldığı için, beklendiği üzere bu araştırmayı desteklememektedir. Buradan üstün zekâlı öğrencilerle normal zekâya sahip öğrencilerin farklı okuma hataları yaptığı sonucu çıkarılmaktadır. Bu durum da üstün zekâlı öğrenciler için farklı bir okuma programım hazırlanması gerekliliğini göstermektedir. Bununla birlikte Şahin (2009) yaptığı araştırmada en sık görülen sesli okuma hatasının "atlayarak okuma" olduğunu tespit etmiştir. Bu durum, bu çalışmadaki sonuçları destekler niteliktedir.

Öğrenci defterlerinin "ilk okuma yazmaya başlama ve ilerleme" aşamasındaki analiz sonuçlarında, yazma bilerek ve yazma bilmeden okula başlayan öğrencilerin ayrı frekansları ve tüm öğrencilerin frekansları incelendiğinde en fazla yük değerine sahip hatanın "kelimedeki harflerin bir ya da birkaçını eksik yazma" hatası olduğu görülmüştür. Yazma hatalarında cinsiyete ilişkin dağıımda kız öğrencilerin hata oranlarının erkek öğrencilerden fazla olduğu görülmüştür. 
Alyıldız (2011) tarafından yapılan araştırmada öğrencilerin "okuma yazmaya başlama ve ilerleme" aşamasında en sık yaptığı hataların "harfleri birbirine yakın yazma" ve "satır sonlarında uygun boşluk bırakmama" olduğunu bulmuştur. Çalışma normal zekâ düzeyindeki öğrencilerle yapılmıştır ve bu durum, bu çalışmadaki bulguları destekler nitelikte değildir. Bu durum da üstün zekâlı öğrenciler için farklı bir yazma programım hazırlanması gerekliliğini ortaya koyabilir.

Öğrenci defterlerinin "bağımsız okuma ve yazma" aşamasındaki analiz sonuçlarında, yazma bilerek okula başlayan öğrencilerin "kelimeye bir ya da birkaç harf ekleyerek yazma" ile yazmayı bilmeden başlayan öğrencilerin "harfleri şekline uygun yazmama" ve "kelimedeki harflerin bir ya da birkaçını eksik yazma" hatalarının en fazla yük değerine sahip hatalar olduğu görülmüştür. Yazma hatalarındaki cinsiyete ilişkin dağılımda kız ve erkek öğrenciler arasında belirgin bir farklılık olmadığı ve tüm öğrencilerin yaptığı en yüksek oranlı hatanın "harfleri şekline uygun yazmama" hatası olduğu saptanmıştır. Phelps, Stempek ve Speck (1985) tarafından yapılan araştırma sonucunda ise öğrencilerin en fazla yaptığı yazma hatanın "harf şekillerinde yapılan hatalar" olduğu tespit edilmiştir. Bu bulgular bu araştırmayı da kısmen destekler niteliktedir.

Yapılan yazım hataları analizi sonucunda üstün zekâlı öğrencilerin "ilk okuma yazmaya başlama ve ilerleme" aşamasında yaptıkları hataların eğitim süreci içerisinde azalması beklenirken, "bağımsız okuma ve yazma" aşamasında "cümleye küçük harfle başlama", "kelimeler arasında fazla boşluk bırakma" ve "satıra yanlış yerden başlayarak yazma" hatalarının arttığı gözlemlenmiştir. Diğer tüm hatalarda azalma görülse de bu durumun sebebi öğrencilere uygulanan hızlandırılmış program olabilir. Bu sebeple üstün zekâlı öğrencilere hızlandırma dışında farklı yöntem ve tekniklerle hazırlanmış ilk okuma ve yazma programı sunulabilir.

\subsection{Sonuç}

Bu bölümde üstün zekâlı birinci sınıf öğrencilerin yaptığı sesli okuma ve yazma hatalarına ilişkin sonuçlar yer almaktadır. Öğrencilere ait yazılı metinler ve videolar incelendiğinde sesli okuma ve yazma hatalarına ilişkin ulaşılan sonuçlar şu şekildedir;

1. Yapılan analiz sonuçlarına göre, öğrencilerin tamamı en fazla hatayı "okurken hece atlama", "vurguya dikkat etmeden okuma", "heceyi tekrarlayarak okuma" ve "heceleri birleştirmeden bağımsız okuma" hatalarında yapmıştır.

2. Analiz sonuçlarına göre, "ilk okuma yazmaya başlama ve ilerleme" aşamasında en fazla "kelimedeki harflerin bir ya da birkaçını eksik yazma" hatası yapılmıştır.

3. Yapılan analiz sonuçlarına göre, "bağımsız okuma ve yazma" aşamasında en fazla "harfleri şekline uygun yazmama" hatası yapılmıştır.

Analiz sonuçlarına göre, "ilk okuma yazmaya başlama ve ilerleme" aşamasından "bağımsız okuma ve yazma" aşamasına geçildikten sonra "cümleye küçük harfle başlama", "kelimeler arasında fazla boşluk bırakma" ve "satıra yanlış yerden başlayarak yazma" hatalarının çoğaldığı saptanmıştır. 


\section{Kaynaklar}

Akyol, H. ve Temur, T. (2008). Ses temelli cümle yöntemi ve cümle yöntemi ile okuma yazma öğrenen öğrencilerin okuma becerilerinin öğretmen görüşlerine göre değerlendirilmesi. Mustafa Kemal Üniversitesi Sosyal Bilimler Enstitüsü Dergisi, 5(9), 79-95.

Alyıldız, A. (2011). Ses temelli cümle yöntemi ile ilk okuma yazma öğretiminde öğrenci hatalarının incelenmesi (Yüksek lisans tezi). Marmara Üniversitesi Eğitim Bilimleri Enstitüsü, İstanbul.

Bloom, B. S. (1982). The role of gifts and markers in the development of talent. Exceptional Children, 48, 510-521.

Clark, B. (2002). Growing up gifted: developing the potential of children at home and at school. New Jersey: Merill Prantice Hall Press.

Coffey, A. \& Atkinson, P. (1996). Making sense of qualitative data: Complementary research strategies. CA: Nembury Park.

Cox, C. M. (1977). Background characteristics of 456 gifted students. The Gifted Child Quarterly, 21, 261-267.

Cutts, N. E. \& Moseley, N. (2004). Üstün zekâlı ve yetenekli çocukların eğitimi: Ulusun en büyük kaynaklarından birinin harcanması nasıl önlenir? (i. Ersevim, Çev.). İstanbul: Özgür Yayıncılık. (Orijinal basım tarihi 2001)

Dale, P.S., Crain-Thoreson, C. \& Robinson, N.M. (1995). Linguistic precocity and developmentof reading: the role o extralinguistic factors. Applied Psycholinguisticd. 16, 173-187.

Elo, S. \& Kyngäs, H. (2007). The qualitative content analysis process. Journal of Advanced Nursing, 62(1), 107-115.

Eriş, B. (2015). Her çocuk üstün yeteneklidir (7. Basım). İstanbul: Alfa Basım Yayın.

Ersoy, A. ve Yalçınoğlu, P. (Çev. Ed.). (2012). Nitel araştırmaya giriş. Ankara: Anı Yayıncılık. (Orijinal basım tarihi 2011).

Freeman, J.J. (Ed.). (1985). The psychology of gifted children: Perspectives on development and education. New York: Wiley.

Hollingworth, L. S. (1942). Children above 180 IQ stanford-binet: origin and development. NY: World Book.

Kahveci, N.G. (2016). Üstün zekâlı ve yetenekliler için eğitim programlarının farklılaştırılması. Özgür Yayınları. 
Louis, B. \& Lewis, M. (1992). Parental beliefs about giftedness in young children and their relation to actual ability level. Gifted Child Quarterly, 36, 27-31.

Martinson, R. A. (1961). Educational programs for gifted pupils. Sacramento, CA: California State Department of Education.

Miles, M.B. \& Huberman, A.M. (1994). Qualitative data analysis: an expanded sourcebook. Calif: SAGE Pyblication.

Phelps, J., Stempels, L. \& Speck, G. (1985). The children's writing scale: A new diagnostic tool. Journal of Educational Research, 79(1), 46-50.

Pilten, G., Temur, T., Şahin, A. ve Demir, E. (2009). Ilk okuma ve yazma öğretimi. Ankara: Pegem Akademi

Price, G. E. \& Milgram, R.M. (1993). The learning styles of gifted adolescents around the World: Differences and similarities. In R. M. Milgram, R. Dunn \& G. E. Price (Eds.), Teaching and counseling gifted and talented adolescents: An international learning-styles perspective. CT: Praeger 229-247.

Sak, U. (2014). Üstün Zekâlılar. (4. Basım). Vize Yayınclık: Ankara

Schiever, S. W. (1985). Creative personality characteristics and dimensions of mental functioning in gifted adolescents. Roeper Review, 7, 223-226.

Şahin, A. (2009). Ses temelli cümle yöntemi, ilk okuma yazma öğretimi. Ankara: Pegem Akademi.

Yıldırım, A. ve Şimşek, H. (2016). Sosyal bilimlerde nitel araştırma yöntemleri. (10. Baskı). Ankara: Seçkin Yayıncılık.

Witty, P.A. (1963). A Balanced Reading Program fort he Gifted. The Reading and the Gifted Child, pp. 418-424. 